\title{
Endoneurial capillary abnormalities in mild human diabetic neuropathy
}

Rayaz A Malik, Aristidis Veves, Ewan A Masson, Ashutosh K Sharma, Antione K Ah-See, Wolfgang Schady, Richard H Lye, Andrew J M Boulton
Department of Anatomy, Aberdeen Royal Infirmary, Aberdeen

A K Sharma

R A Malik

A K Ah-See

Department of Surgery, Aberdeen Royal Infirmary

Department of Medicine, Manchester Royal Infirmary,

Manchester

A J M Boulton

A Veves

E A Masson

Department of

Neurology,

Manchester Royal

Infirmary

W Schady

Department of

Neurosurgery,

Manchester Royal

Infirmary

R H Lye

Correspondence to: Dr Boulton, University Department of Medicine, Manchester Royal Infirmary Oxford Road, Manchester M13 9WL

Received 23 April 1991 and in revised form 15 August 199

Accepted 28 August 1991

\begin{abstract}
Microvascular factors have been implicated in the pathogenesis of human diabetic neuropathy. The extent of microangiopathy was assessed in 15 diabetic patients with clinically mild neuropathy and compared with eight age matched control subjects. Endoneurial capillary density was reduced $(p<0.04)$ and correlated significantly with reduced myelinated fibre density ( $p<0 \cdot 01)$. Both basement membrane area $(p<0.0001)$ and endothelial cell profile number per capillary $(p<0.002)$ were significantly increased in diabetic patients and correlated significantly with both neurophysiological and neuropathological measures of neuropathic severity. There was no evidence of endothelial cell hypertrophy as assessed by either cross sectional endothelial cell area or a reduction in luminal size. Furthermore, the percentage of closed vessels did not differ between diabetic patients and control subjects and failed to relate to measures of neuropathic severity. It was concluded that microvascular abnormalities are prominent in patients with clinically mild human diabetic neuropathy, and that these data provide further support for the role of endoneurial capillary disease in the development of this condition.
\end{abstract}

The cause of human diabetic neuropathy is considered to be multifactorial, " with both metabolic $^{2}$ and ischaemic ${ }^{3-5}$ factors playing an important part. Whereas much recent research has focused on the polyol pathway and related metabolic abnormalities in relation to the aetiopathogenesis of human diabetic neuropathy, ${ }^{6-9}$ several studies have characterised the presence of microangiopathy in patients with established human diabetic neuropathy. ${ }^{40-16}$ Thus a considerable amount of evidence has accumulated on the role of microvessel disease and resultant hypoxia in the development of neuropathy. ${ }^{3-5}{ }^{17-19}$ Fibre loss in human diabetic neuropathy has been shown to be multifocal, providing further support for a role of ischaemia in its development. ${ }^{2021} \mathrm{~A}$ recent study has also shown that multifocal fibre loss and hence ischaemia may well play an important part in the development of neuropathy in older non-insulin dependent diabetic patients. ${ }^{22}$ However, more recent studies on the pattern of fibre loss ${ }^{23}$ and extent of microangiography ${ }^{15}$ have failed to support these earlier findings.
A microvascular basis to human diabetic neuropathy cannot, however, be discounted and this subject requires further systematic study. We examined microvascular abnormalities in a group of patients with clinically mild neuropathy and attempted to relate these abnormalities to measures of neuropathic severity.

\section{Materials and methods}

SUBJECTS

Fifteen patients (12 men and three women) with mild diabetic neuropathy were studied; all fulfilled the following criteria ${ }^{24}$ : $(a)$ either no symptoms or a history of mild neuropathic symptomatology; (b) no history of foot ulceration, peripheral vascular disease, renal disease, or any other conditions known to cause neuropathy; (c) evidence of reduced but not absent sensation in the feet to both small and large fibre modalities, and with normal foot pulses; (d) vibration perception threshold by a biothesiometer over the medial malleolus above the 95th centile for the age matched normal value but $<40$ volts; (e) peroneal nerve motor conduction velocity below the 5 th centile for the age matched normal value, but $>30 \mathrm{~m} / \mathrm{s}$; ( $f$ ) normal serum creatinine concentration $(<130 \mu \mathrm{mol} / \mathrm{l})$.

All electrophysiological nerve parameters were assessed by the same neurophysiologist (WS). The study was approved by the Central Manchester Hospitals Ethical Committee and all patients gave written informed consent after the nature of the procedures had been explained.

\section{TISSUE BIOPSY}

Fascicular sural nerve biopsy was performed under local anaesthesia by a consultant neurosurgeon (RHL). For ultrastructural examination the nerve specimen was fixed primarily in glutaraldehyde in cacodylate buffer and secondarily in osmium tetroxide. After dehydration in a graded series of ethanol the tissue was embedded in epon resin with propylene oxide as an intermediary. Sural nerve biopsies of six age matched organ donors and two patients with traumatic amputation were used as controls. All such patients had normal cardiovascular and renal function and no known cause of peripheral neuropathy before biopsy by the same surgeon.

\section{HISTOLOGICAL AND MORPHOMETRIC PROCEDURES} The myelinated fibre density was derived by directly counting fibres from montages ( $\times 1000)$ of all fascicles from the biopsies. 
Table 1 Results of peripheral nerve electrophysiology and quantitative sensory tests in diabetic patients

\begin{tabular}{llr}
\hline & $\begin{array}{l}\text { Diabetic patients } \\
(n=15)\end{array}$ & \% Abnormal \\
\hline Mean (SE) peroneal motor nerve conduction velocity $(\mathrm{m} / \mathrm{s})$ & $37 \cdot 3(3 \cdot 3)$ & 100 \\
Mean (SE) sural nerve conduction velocity $(\mathrm{m} / \mathrm{s})$ & $38 \cdot 6(5 \cdot 4)$ & 66 \\
Mean (SE) sural sensory action potential amplitude $(\mu \mathrm{V})$ & $5 \cdot 4(4 \cdot 5)$ & 40 \\
Mean (SE) vibration perception threshold (volts) & $26 \cdot 4(7 \cdot 0)$ & 100 \\
Mean (SE) thermal discrimination threshold $\left({ }^{\circ} \mathrm{C}\right)$ & $3.6(7 \cdot 2)$ & 63 \\
\hline
\end{tabular}

Mean fascicular area and endoneurial capillary density were assessed directly from semithin sections, stained with thiomin and acridine orange, by using a camera lucida (Nachet, Evry, France) and sonic digitiser. All microvessels without a complete layer of cells (pericyte or smooth muscle cells) surrounding the

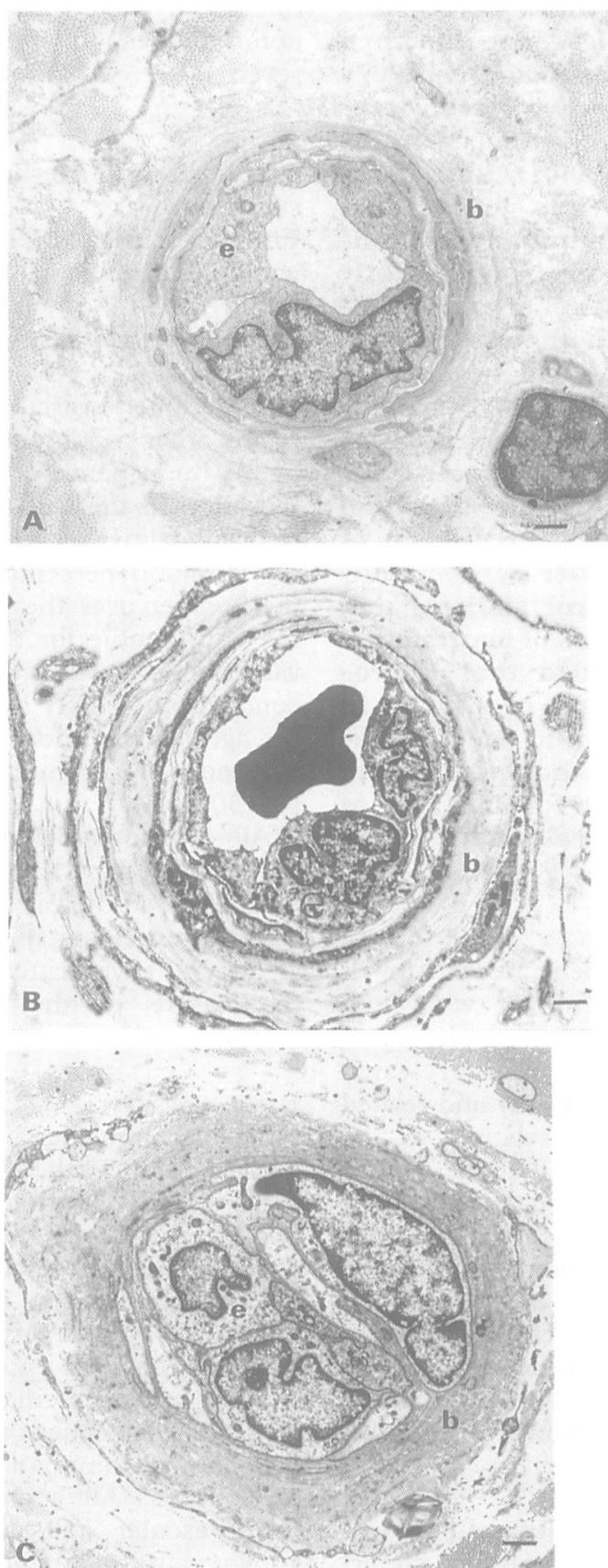

Figure 1 Electron micrographs of endoneurial capillaries in control subject aged 55 years $(A)$ and diabetic patients aged 56 years $(B)$ and 55 years $(C)$ with mild diabetic neuropathy, showing endothelial cell (e) proliferation and basement membrane (b) thickening and, in diabetic patients, open (B) and closed vessels (C). Bars = $1 \mu \mathrm{m}$. endothelial cells were considered to be capillaries and were photographed at a final magnification of $\times 10000-15000$. The luminal, endothelial cell, and basement membrane areas were derived from programmed digitisation (Commodore PET Microcomputer Systems) of each electron micrograph. The endothelial cell profile and nuclear number and pericyte nuclear number per capillary were counted directly from the electron micrographs by using previously described techniques. ${ }^{45} \mathrm{Clo}-$ sure of endoneurial vessels was assessed by surveying all vessels by electron microscopy. When endothelial cell surfaces were apposed in the midline of any vessel it was considered to be closed (fig 1C).

\section{STATISTICAL ANALYSIS}

Differences between groups were tested using the two tailed Mann-Whitney U test. Spearman's rank correlation coefficients were calculated using the University of Aberdeen Honeywell Bull DPS8/70 mainframe computer and Minitab statistical package.

\section{Results}

CLINICAL AND NEUROPHYSIOLOGICAL DETAILS

The mean age of control subjects was 47.5 (median $47 \cdot 5$, SD $26 \cdot 5$, range $18-85$ ) years. The mean age of the diabetic patients was 46.9 (median 48.0, SD 10.9, range 27-59) years and the mean duration of diabetes was $16 \cdot 3$ years. Seven patients had insulin dependent diabetes and eight had non-insulin dependent diabetes. All but three subjects had preserved ankle reflexes. Details of electrophysiological and quantitative sensory testing are provided in table 1 . Sural nerve conduction velocity was normal in one third of patients. Sural action potentials were recordable in all patients and were of normal amplitude in $60 \%$. According to published criteria ${ }^{25}$ the patients in this study would be classified as having either stage 2 (asymptomatic) or stage 2 (symptomatic) neuropathy.

\section{MICROANGIOPATHY}

Qualitative observations-Electron micrographs of representative vessels from control subjects and diabetic patients are presented in figure 1 . The basement membrane was considerably thickened in the form of concentric, reduplicated layers. Endothelial cells showed hyperplasia as did pericyte profiles and there was no evidence of either endothelial or pericyte cell degeneration. Both semithin and ultrathin sections failed to show vascular occlusion with fibrin or platelets, and no inflammatory infiltrates were observed in the endoneurium, perineurium, or epineurium. The perineurium itself was observed to be thickened in diabetic patients.

Quantitative observations-Capillary density $(\mathrm{p}<0.04)$ and myelinated fibre density $(\mathrm{p}<$ 0.01 ) were significantly reduced in diabetic patients, without a significant increase in fascicular area. Basement membrane area $(\mathrm{p}<$ $0.0001)$, endothelial cell profile $(p<0.002)$, and pericyte nuclear number $(p<0.02)$ per 
Table 2 Endoneurial capillary morphometry in diabetic patients and age matched control subjects presented as mean (SE)

\begin{tabular}{|c|c|c|c|}
\hline Parameter & $\begin{array}{l}\text { Control subjects } \\
(n=8)\end{array}$ & $\begin{array}{l}\text { Diabetic patients } \\
(n=15)\end{array}$ & $p$ Value \\
\hline Age (years) & $47.50(9 \cdot 3)$ & $46.9(3 \cdot 0)$ & NS \\
\hline Age (range) & $(18-85)$ & $(27-59)$ & \\
\hline Mean fascicular area $\left(\mathrm{mm}^{2}\right)$ & $0.09(0.01)$ & $0 \cdot 12(0.02)$ & NS \\
\hline Myelinated fibre density $\left(\mathrm{No} / \mathrm{mm}^{2}\right)$ & $6561(407)$ & $4042(540)$ & 0.01 \\
\hline Capillary density $\left(\mathrm{No} / \mathrm{mm}^{2}\right)$ & $67 \cdot 9(4 \cdot 8)$ & $53.32(4.4)$ & $0 \cdot 04$ \\
\hline Basement membrane area $\left(\mu \mathrm{m}^{2}\right)$ & $47 \cdot 34(5 \cdot 37)$ & $156.5(15.9)$ & 0.0001 \\
\hline Endothelial cell area $\left(\mu \mathrm{m}^{2}\right)$ & $32.54(6 \cdot 18)$ & $25.59(3.32)$ & NS \\
\hline Luminal area $\left(\mu \mathrm{m}^{2}\right)$ & $32.61(3.71)$ & $44 \cdot 87(5 \cdot 45)$ & NS \\
\hline Endothelial cell profile number & $4 \cdot 10(0 \cdot 30)$ & $5 \cdot 87(0 \cdot 21)$ & 0.002 \\
\hline Endothelial cell nuclear number & $1.20(0 \cdot 10)$ & $1.68(0.12)$ & NS \\
\hline Pericyte nuclear number & $0.59(0.05)$ & $0.83(0.08)$ & 0.02 \\
\hline Endothelial-pericyte cell nuclear ratio & $2 \cdot 30(0 \cdot 20)$ & $2 \cdot 26(0 \cdot 26)$ & NS \\
\hline
\end{tabular}

capillary were significantly increased in diabetic patients (table 2). The endothelial-pericyte cell nuclear ratio were similar in control subjects and diabetic patients (table 2). The endothelial cell area was slightly lower in

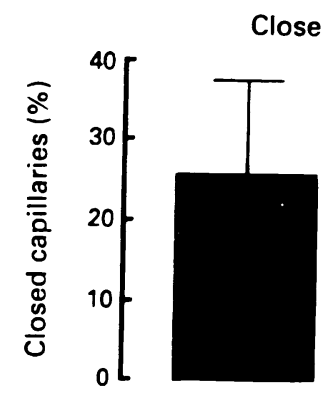

losed capillaries
Endothelial cell area

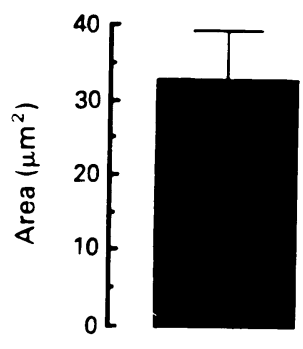

Control

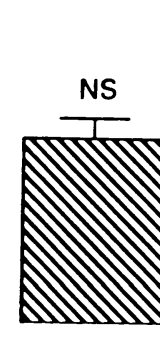

Diabetic

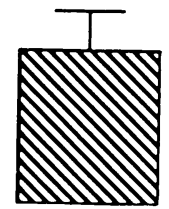

Luminal area

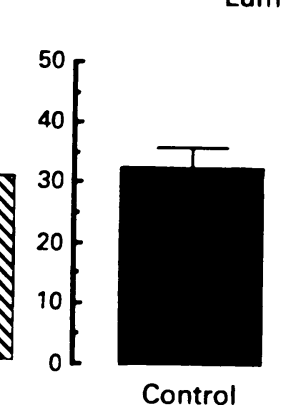

diabetic patients than in control subjects. Furthermore, the luminal area was slightly greater in diabetic patients than in control subjects, and the percentage of closed capillaries was in fact slightly less in diabetic patients than in control subjects (fig 2). These differences were not statistically significant.

CORRELATION BETWEEN MICROANGIOPATHY AND NELROPATHY

Capillary density correlated directly with myelinated fibre density $(\mathrm{p}<0.01)$ (table 3 ). Basement membrane area also correlated inversely with peroneal motor $(\mathrm{p}<0.05)$ and sural sensory $(\mathrm{p}<0.05)$ nerve conduction velocity and myelinated fibre density $(\mathrm{p}<$ $0 \cdot 05$ ) (fig 3). Endothelial cell profile number correlated inversely with peroneal motor conduction velocity $(\mathrm{p}<0.01)$ and myelinated fibre density ( $p<0.05$ ) (fig 3 ). Endothelial cell area was not significantly increased, but it correlated inversely with sural nerve conduction velocity $(p<0.05)$. Luminal area was increased and correlated inversely with peroneal $(\mathrm{p}<0.01)$ and sural $(\mathrm{p}<0.05)$ nerve conduction velocity. Vessel closure was not related to any of the measures of neuropathic severity (table 3). Measures of endoneurial microangiopathy showed no significant relation with age or with thermal and vibration perception thresholds (table 3).

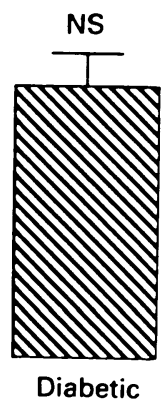

Figure 2 Percentage of closed endoneurial capillaries (top) and endothelial cell and luminal area (bottom) in diabetic patients and control subjects $\mathrm{NW}$ expressed as mean (SE).
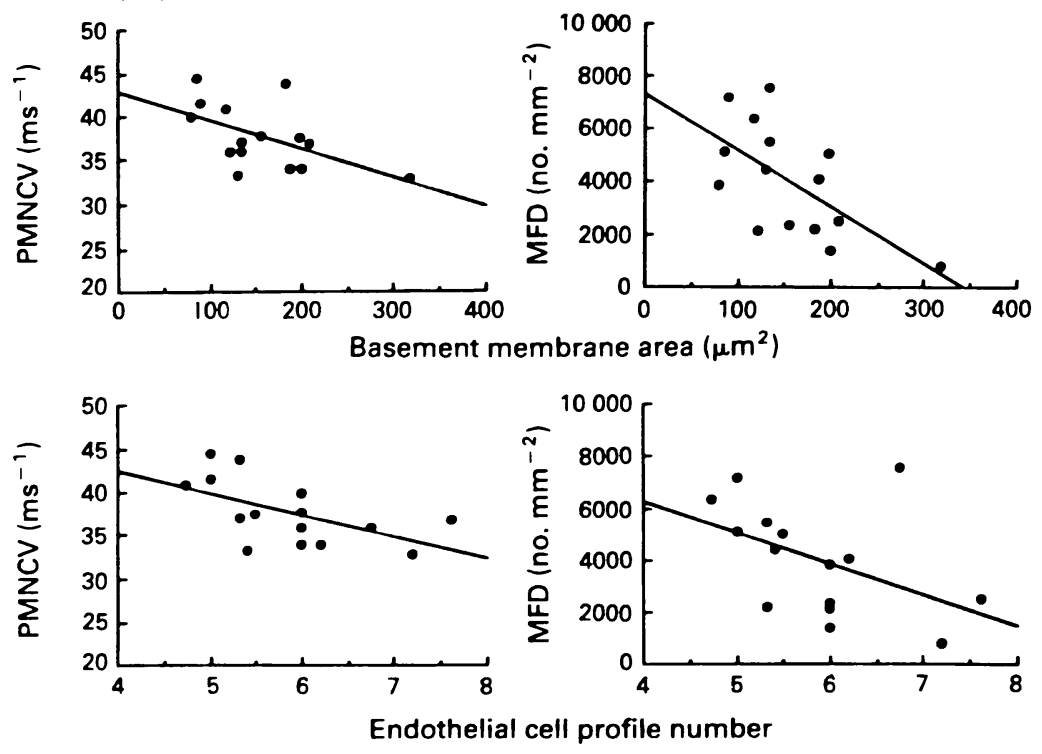

Figure 3 Correlation plots between PMCV (peroneal motor conduction velocity) and MFD (myelinated fibre density) with basement membrane area (top) and endothelial cell profile number (bottom).

\section{Discussion}

Microangiopathy is prominent in the endoneurial vessels of patients with established human diabetic neuropathy. ${ }^{+13}{ }^{15}$ We have now studied diabetic patients with clinically mild neuropathy and have shown significant endoneurial microangiopathy, which relates to measures of neuropathic severity. The mild nature of neuropathy is supported by the electrophysiological results where sural action potentials were recordable in all patients and were of normal amplitude in $60 \%$ while the nerve conduction velocity was normal in one third of patients.

A reduction in capillary density was observed without a significant increase in fascicular area, confirming our previous findings in patients with severe neuropathy. ${ }^{4}$ Such a reduction would be expected to increase intercapillary distance and reduce nerve blood flow and hence endoneurial oxygen levels. ${ }^{17} 18$ A recent study showed an increase in capillary density in patients with newly presenting and chronic painful neuropathy and a decrease in those patients with recurrent foot ulceration. ${ }^{14}$ Such a disparity in capillary density among different syndromes of diabetic neuropathy would perhaps explain the failure of a recent study to find any difference in capillary density between diabetic patients and control subjects ${ }^{15}$ as it incorporated patients with a variety of different syndromes of diabetic neuropathy, including those with foot ulceration.

Endothelial cells exhibit both hyperplasia and hypertrophy in established diabetic neuropathy ${ }^{4116}$ and they are known to be markers of a range of metabolic, haemostatic, and 
Table 3 Correlation of capillary morphometry with age, nerve electrophysiology, myelinated fibre density and sensory testing presented as Spearman's rank correlation coefficient and degree of significance

\begin{tabular}{|c|c|c|c|c|c|c|c|}
\hline & Age & PNCV & SNCV & $S N A P$ & $M F D$ & $V P T$ & $T D T$ \\
\hline $\begin{array}{l}\text { Capillary density }\left(\mathrm{no} / \mathrm{mm}^{2}\right) \\
\text { Basement membrane area }\left(\mu \mathrm{m}^{2}\right) \\
\text { Endothelial cell profile number } \\
\text { Endothelial cell area }\left(\mu \mathrm{m}^{2}\right) \\
\text { Luminal area }\left(\mu \mathrm{m}^{2}\right) \\
\text { Closed capillaries }(\%)\end{array}$ & $\begin{array}{l}0.11 \\
\text { NS } \\
0.21 \\
\text { NS } \\
0.21 \\
\text { NS } \\
0.19 \\
\text { NS } \\
0 \cdot 19 \\
\text { NS } \\
0.17 \\
\text { NS }\end{array}$ & $\begin{array}{l}0.25 \\
\text { NS } \\
-0.55 \\
(p<0.05) \\
-0.68 \\
(p<0.05) \\
-0.48 \\
\text { NS } \\
-0.70 \\
(p<0.01) \\
0.15 \\
\text { NS }\end{array}$ & $\begin{array}{l}\quad 0.44 \\
\text { NS } \\
-0.55 \\
(p<0.05) \\
-0.46 \\
\text { NS } \\
-0.52 \\
(p<0.05) \\
-0.49 \\
(p<0.05) \\
0.08 \\
\text { NS }\end{array}$ & $\begin{array}{l}0 \cdot 29 \\
\text { NS } \\
-0 \cdot 29 \\
\text { NS } \\
-0 \cdot 25 \\
\text { NS } \\
-0 \cdot 10 \\
\text { NS } \\
-0 \cdot 44 \\
\text { NS } \\
0 \cdot 29 \\
\text { NS }\end{array}$ & $\begin{array}{l}0.65 \\
(p<0.01) \\
-0.52 \\
(p<0.05) \\
-0.49 \\
(p<0.05) \\
-0.39 \\
N S \\
-0.46 \\
\text { NS } \\
-0.08 \\
\text { NS }\end{array}$ & $\begin{array}{c}0.30 \\
\text { NS } \\
0.19 \\
\text { NS } \\
0.39 \\
\text { NS } \\
0.13 \\
\text { NS } \\
0.36 \\
\text { NS } \\
-0.09 \\
\text { NS }\end{array}$ & $\begin{array}{l}0 \cdot 12 \\
\text { NS } \\
0 \cdot 38 \\
\text { NS } \\
0 \cdot 44 \\
\text { NS } \\
0 \cdot 16 \\
\text { NS } \\
0 \cdot 46 \\
\text { NS } \\
0 \cdot 07 \\
\text { NS }\end{array}$ \\
\hline
\end{tabular}

PNCV = Peroneal motor conduction velocity, SNCV = Sural nerve conduction velocity, SNAP = Sural nerve action potential, MFD = Myelinated fibre density, VPT = Vibration perception threshold, TDT $=$ Thermal discrimination threshold.

pathological abnormalities in diabetic patients. ${ }^{26}$ We found endothelial cell hyperplasia, which again confirms previous findings in patients with established neuropathy. ${ }^{41-16}$ Other studies have also found endothelial cell hypertrophy in patients with established neuropathy. ${ }^{41-1315}$ However, the present study, which included patients with clinically mild neuropathy, failed to show this, in keeping with previous studies that have included some patients with mild neuropathy ${ }^{4}$ and without neuropathy. ${ }^{413}$ Thus endothelial cell hypertrophy may well be a late feature of diabetic microangiopathy.

Pericyte cell nuclear hyperplasia was observed, confirming previous findings in established neuropathy. ${ }^{413}$ Basement membrane thickening was also found in the present study. ${ }^{40-15}$ It has been described in a range of acquired $^{27}$ and inherited neuropathies ${ }^{15}$ and is presumably due to primary precapillary denervation and hence capillary hypertension. ${ }^{28}$ In diabetes both primary precapillary denervation ${ }^{28}$ and the reduced degradation of basement membrane due to glycosylation ${ }^{29}$ have central roles. It is therefore not surprising that a recent study of hereditary motor and sensory neuropathy found basement membrane thickening and increased luminal size almost comparable to those in diabetic patients with neuropathy. ${ }^{15}$ Therefore these abnormalities result in limited vascular reactivity and hence abnormal microvascular function. ${ }^{30-32}$

We did not find luminal occlusion on direct electron microscopic observation of vessel closure and from morphometric assessment of luminal size, contrary to the observations of a previous study. ${ }^{16}$ Support for our findings is found in other ultrastructural studies that have shown an increase in luminal size. ${ }^{412-15} \mathrm{We}$ also failed to find any relation between extent of vessel closure and measures of neuropathic severity, confirming a previous finding. ${ }^{13}$

A range of microvascular abnormalities was correlated with measures of neuropathic severity such as loss of myelinated fibres and neurophysiological abnormalities. This has been shown previously in patients with established neuropathy. ${ }^{41314}$ However, all measures of microangiography failed to relate to age and abnormalities of either vibration or thermal perception. This finding may simply reflect the large coefficient of variation inherent in these tests. ${ }^{33} 34$

In conclusion, we clearly showed a micro- angiopathy in patients with clinically mild neuropathy, which relates significantly to measures of neuropathic severity. These findings provide further support for the role of small vessel disease in the development of human diabetic neuropathy.

We thank Mr J Engeset for providing some normal control biopsies and Mrs M Moir for typing the manuscript. This work was partly supported by a research grant from ICI plc.

1 Thomas PK. The pathogenesis of diabetic neuropathy: current problems and prospects. In: Ward JD, GotoY, eds. Diabetic neuropathy. Chichester: Wiley, 1990:3-16.

2 Greene DA, Lattimer SA, Sima AAF. Sorbital, phosphoinositol and sodium-potassium-ATPase in the pathogenesis
of diabetic complications. N Engl $\varsubsetneqq$ Med 1987;316: of diabetic

3 Dyck PJ. Hypoxic neuropathy: does hypoxia play a role in diabetic neuropathy? Neurology 1989;39:111-8.

4 Malik RA, Newrick PG, Sharma AK, Ah-See AK, Mayhew $\mathrm{TM}$, Jakubowski $\mathrm{J}$, et al. Microangiopathy in human diabetic neuropathy: relationship between capillary abnormalities and the severity of neuropathy. Diabetologia 1989;32:92-102.

5 Malik RA, Masson EA, Sharma AK, Lye RH, Ah-See AK, Compton AM, et al. Hypoxic neuropathy: relevance to human diabetic neuropathy. Diabetologia 1990;33: 311-8.

6 Dyck PJ, Zimmerman BR, Vilen TH, Minnerath BR, Karnes JL, Yao JK, et al. Nerve glucose, fructose, sorbitol, myoinositol, and fibre degeneration and regeneration in myoinositol, and fibre degeneration and regeneration

7 Sima AAF, Bril V, Nathaniel V, McEwen TAJ, Brown MB Lattimer SA, et al. Regeneration and repair of myelinated fibres in sural nerve biopsy specimens from patients with diabetic neuropathy treated with Sorbinil. $N$ Engl f Med 1988;319:548-55.

8 Dyck PJ, Sherman WR, Hallcher LM, Service FJ, O'Brien PC, Grisa LA, et al. Human diabetic endoneurial sorbitol, fructose, and myoinositol related to sural nerve morphometry. Ann Neurol 1980;8:590-6.

9 Hale PJ, Nattrass M, Sliverman SH, Sennit C, Perkins CM, Uden A, et al. Peripheral nerve concentrations of glucose, fructose, sorbitol and myoinositol in diabetic and nondiabetic patients. Diabetologia 1987;30:464-7.

10 Fagerberg SE. Diabetic neuropathy: a clinical and histological study on the significance of vascular affections. tological study on the significance of vascular

11 Timperley WR, Boulton AJM, Davies-Jones GAB, Jarrat JA, Ward JD. Small vessel disease in progressive diabetic JA, Ward JD. Small vessel disease in progressive diabetic neuropathy associated with

12 Powell HC, Rosoff J, Myers RR. Microangiopathy in human diabetic neuropathy. Acta Neuropathol (Berl) 1985;68: 295-305.

13 Yasuda H, Dyck PJ. Abnormalities of endoneurial microvessels and sural nerve pathology in diabetic neuropathy. Neurology 1987;37:20-8.

14 Britland ST, Young RJ, Sharma AK, Clarke BF. Relationship of endoneurial capillary abnormalities to type and severity of diabetic polyneuropathy. Diabetes 1990;39: 909-13.

15 Bradley J, Thomas PK, King RHM, Llewelyn JG, Muddle JR, Watkins PJ. Morphometry of endoneurial capillaries in diabetic sensory and autonomic neuropathy. Diabetologia 1990;33:611-8.

16 Dyck PJ, Hansen S, Karnes J, O'Brien P, Yasada $H$ Windebank $A$, et al. Capillary number and percentage closed in human diabetic sural nerve. Proc Natl Acad Sci Closed in human diabe

17 Low PA, Tuck RR, Takeuchi M. Nerve microenvironment in diabetic neuropathy. In: Dyck PJ, Thomas PK, Asbury AK, Winegrad AI, Porte D, eds. D

18 Newrick PG, Wilson AJ, Jakubowski J, Boulton AJM, Ward JD. Sural nerve oxygen tension in diabetes. $B M \mathcal{F}$ 
1986;293:1053-4.

19 Paramelle B, Vila A, Pollak P, Muller P, Gavelle D, Reymond $\mathrm{F}$, et al. Frequence des polyneuropathies dans les bronchopneumopathies chroniques obstructive. La Presse Medicale 1986;12:563-7.

20 Dyck PJ, Karnes JL, O'Brien P. The spatial distribution of fibre loss in diabetic polyneuropathy suggests ischaemia. Ann Neurol 1986:19:440-9.

21 Johnson PC, Doll SC, Cromey DW. Pathogenesis of diabetic neuropathy. Ann Neurol 1986;19:450-7.

22 Sima AAF, Nathaniel V, Bril V, McEwen TAJ, Greene DA. Histopathological heterogeneity of neuropathy in insulin dependent and non-insulin dependent diabetes, and demonstration of axo-glial dysjunction in human diabetic neuropathy. $f$ Clin Invest 1988;81:349-64.

23 Llewelyn JG, Thomas PK, Gilbey SD, Watkins PI, Muddle JR. Pattern of myelinated fibre loss in the sural nerve in neuropathy related to type 1 (insulin-dependent) diabetes. Diabetologia 1988;31:162-7.

24 Armstrong FM, Bradbury JE, Ellis SH, Owens DR, Rosen I, Sonksen P, et al. A study of peripheral diabetic neuropathy: the application of age-related reference neuropathy: the application of age-related
values. Diabetic Med 1991;8(suppl 1):594-9.

25 Dyck PJ. Detection, characterization and staging of polyneuropathy: assessed in diabetics. Muscle and Nerve neuropathy: ass

26 Porta M, La Selva M, Molinatti P, Mollinatti GM. Endothelial cell function in diabetic microangiopathy. Diabetologia 1987;30:601-9.
27 Behse F, Bucthal F, Carlsen P. Nerve biopsy and nerve conduction studies in diabetic neuropathy. 7 Neurol Neurosurg Psychiatry 1977;30:1072-82.

28 Williamson JR, Kilo C. Current status of capillary basement membrane disease in diabetes mellitus. Diabetes 1977 ; 26:65-75.

29 Cohen MP, Urdanivia E, Surma M, Ciborowski JC. Nonenzymatic glycosylation of basement membranes. Diabetes 1981;30:367-71.

30 Kastrup J, Norgaard T, Parving HH, Lassen NA. Decreased distensibility of resistance vessels of the skin in type I (insulin dependent) diabetic patients with microangiopathy. Clin Sci 1987;72:123-30.

31 Rayman G, Williams SA, Spencer PA, Smaje LH, Wise PH Tooke JE. Impaired microvascular hyperaemic response to minor skin trauma in type I diabetes. $B M \mathcal{F} 1986 ; 292$ : 1295-8.

32 Malik RA, Rayman G, Metcalfe J, Sharma AK, Day JL Impaired diabetic hyperaemic responses relate to skin capillary basement membrane but not endothelial or pericyte cell abnormalities. Diabetologia 1989;32:A514.

33 Williams G, Gill JS, Aber V, Mather HM. Variability in vibration perception threshold among sites: a potential vibration perception threshold among sites: a potential
source of error in biothesiometry. BMf 1988;296: source

34 Attali JR, Valensi $P$, French group for research and study of diabetic neuropathy: Reproducibility of the parameters of nerve function investigations in diabetes. Diabetologia 1990;33:A15. 